\title{
Juridical Analysis Of Application Of Forgiveness (Rechterlijk Pardon) As A Basis Of Judge Consideration In Deciding The Criminal
}

\author{
Sisno Pujinoto ${ }^{1}$, Anis Mashdurohatun ${ }^{2}$ and Achmad Sulchan ${ }^{3}$
}

Abstract. The formulation of the problem in this study are: How is the principle position Rechterlijk Pardon in the criminal system in Indonesia, how the principles are applied Rechterlijk Pardon in a criminal ruling Decision Number 241 / Pid.B / 2019 / PN.Mjl andHow the development / concept of the Rechterlijk Pardon principle in the renewal of the Indonesian criminal law that will come related to the draft criminal law on the monodualistic principle?This study uses a sociological juridical approach, with descriptive analytical research specifications. The data used in this study are secondary data obtained through library research and primary data obtained through field research which are then analyzed qualitatively using legal theory, the forgiveness agency theory, criminal justice system theory, and progressive legal theory. Based on the results of that study The position of the Rechterlijk Pardon Principle in the Criminal System in Indonesia is forgiveness is a form of forgiveness / deliverance from mistakes made. As a form of forgiveness, then with forgiveness, someone who is guilty is not sentenced or does not need to feel the punishment. Provisions such as this basically exist in conditional criminal conduct (voorwaardelijke veroordeling) regulated in Article 14a-14f of the Criminal Code. Conditional penalties are also referred to by part of the community with the term criminal trial or there is also termed as conditional punishment. Application of the Rechterlijk Pardon Principle in Criminal Verdicts Number 241 / Pid.B / 2019 / PN.Mjl it is applied later to act as the final safety valve in the criminal justice system if a case is not filtered at the prosecution and preliminary hearing judge stage. Development / Concept of the Rechterlijk Pardon Principle in the Future Renewal of Indonesian Criminal Laws Associated with the Draft Criminal Laws on the Monodualistic Principle are Forgiveness institution, is an important element to answer problems that cannot be accommodated with only 3 (three) types of decisions (free, loose, criminal funds).

Keywords : Institutions; Forgiveness; Rechterlijk Pardon; Considerations; Judges; Decisions.

\section{Introduction}

Criminal law as a branch of applicable law, in addition to civil law, state administration law, and State administrative law, basically aims to protect and protect the public interest, in this case the public ${ }^{4}$. So that criminal acts that occur are not merely seen as violations of individual interests, but are also considered as violations of the rule of law. Where is mentioned that the crime itself is a social institution that is related and reflects the values and structure of society. For this reason, criminal law should be a sublimation of all values in society which are then applied by the authorities in the criminal justice system ${ }^{5}$.

\footnotetext{
${ }^{1}$ Student of Master of Law, Universitas Islam Sultan Agung Semarang and Member of the Indonesian Armed Forces, email: sisnopujinoto@yahoo.com

${ }^{2}$ Lecturer of Faculty of Law, Sultan Agung Islamic University (Unissula) Semarang

${ }^{3}$ Lecturer of Faculty of Law, Sultan Agung Islamic University (Unissula) Semarang

${ }^{4}$ Bambang Poernomo, 1993, Asas-asas Hukum Pidana, Ed. Revised, Ghalia Indonesia, Jakarta, p. 37.

${ }^{5}$ Harkristuti Harkrisnowo, 2003, "Rekonstruksi Konsep Pemidanaan: Suatu Gugatan Terhadap Proses Legislasi dan Pemidanaan di Indonesia," Oration at the Inauguration Ceremony of Professors in Criminal
} 
According to Achmad Sulchan, in the lecture notes stated that the theory is a construction in the minds of human ideals or ideas that are built with the intention to manifest / reflect reflective and phenomena encountered in his experience. ${ }^{6}$

Conviction is a criminal conviction / sentencing as a lawful attempt to charge someone or more in the form of suffering committed through a criminal justice process which if proven legally and convincingly guilty of committing a crime ${ }^{7}$. In the branch of criminal science, this provision is called penitentiary law (sanction law). Understanding penitentiary law in general, namely all positive regulations regarding the system of punishment (strafstelsel) and the system of action (matregelstelsel) ${ }^{8}$.

Indonesian criminal law in force today is a legacy from the Netherlands (Het Wetboek van Stafrecht) based on Act No. 1 of 1946, the criminal law in force in the Dutch East Indies becomes Indonesian criminal law (KUHP). The Dutch inheritance law has lagged far behind the development of society and the need for better criminal law ${ }^{9}$. Especially with regard to criminality, it is currently considered unsatisfactory to the public. This has triggered a number of ideas to make alternative efforts in answering issues relating to the handling of criminal acts. Issues surrounding the development of the existing criminal justice system show that this system is no longer considered to be able to provide protection for human rights and transparency in the public interest ${ }^{10}$.

Based on the background of the problem stated above, the problem formulated is as follows: How is the principle position Rechterlijk Pardon in the criminal system in Indonesia? How the principles apply Rechterlijk Pardon in a criminal ruling Decision Number241 / Pid.B / 2019 / PN.Mjl? How the development / concept of the Rechterlijk Pardon principle in the renewal of the Indonesian criminal law that will come related to the draft criminal law on the monodualistic principle?

\section{Research methods}

The method used by researchers is juridical sociological legal approach and The specifications in this study include descriptive analysis. The sources and types of data in this study are primary data obtained from interview field studies with Judges of the Majalengka District Court. And secondary data obtained from library research.

\section{Results And Discussion}

\subsection{Principal Position Rechterlijk Pardon In the Criminal System in Indonesia}

Peace institutions in the national legal system have long been established, especially in the field of civil case settlement. The application of peace efforts (dading institutions) is

Law, Faculty of Law, University of Indonesia at the University of Indonesia Convention Center, Depok March 8, 2003, p. 2

${ }^{6}$ Achmad Sulchan, 2017, Catatan Kuliah Teori Hukum dan Penemuan Hukum, of Faculty of Law, Unissula, Semarang.

7 Andi Hamzah, 1986, Sistem Pidana dan Pemidanaan Indonesia dari Retribusi ke Reformasi,, print. I, Pradnya Paramita, Jakarta, p. 12

${ }^{8}$ Tolib Setiady, 2010, Pokok-Pokok Hukum Penitensier Indonesia, Alfabeta, Bandung, p. 77.

${ }^{9}$ Agus Rusianto, 2016, Tindak Pidana \& Pertanggungjawaban Pidana: Tinjauan Kritis Melalui Konsistensi antara Asas, Teori, dan Penerapannya, Kencana, Jakarta, p. 1

${ }^{10}$ Eva Achjani Zulfa, 2011, Pergeseran Paradigma Pemidanaan, Lubuk Agung, Bandung, p. 2 
determined in Article 130 HIR / Article 154 RBg. After the reformation, the Government enacted Act No. 30 Year 1999 concerning Arbitration and Alternative Dispute Resolution. This law has provided a special place for the existence of alternative dispute resolution outside the litigation process.

Criminal law tends to be a refinement of other legal regulations, where criminal law as a knife that limits the authority and rights of a person, we often hear that criminal law is the last alternative used in resolving a conflict arising from a shift in rights between communities. On one side, criminal law will protect someone's rights, but on the other hand, it also limits and deprives someone else of their rights by using formal justice ${ }^{11}$.

Based on the above research, according to the authors reviewed from Theory of the Institute of Forgiveness (Rechterlijk Pardon), the theory of the criminal justice system and the theory of progressive law, the judgment of the judge in cases decided by the District Court NorthEast Number 46 / Pid / 78 / UT / Wan, in line with the three theories used as the analysis knife in this study.

Criminal forgiveness is not a legal remedy (rechtsmiddel) in criminal procedural law, and the arena is not a right granted to the defendant or the public prosecutor. whereas forgiveness has another purpose, which is to abolish the implementation even though the principle is that the law must be upheld, in special cases forgivennes by not implementing the law. Thus the verdict District Court North-East Number 46 / Pid / 78 / UT / Wan, can be interpreted as a form of Forgiveness Agency (Rechterlijk Pardon). ${ }^{12}$

The position of the Rechterlijk Pardon Principle in the Criminal System in Indonesia is for giveness is a form of forgiveness / deliverance from mistakes made. As a form of forgiveness, then with forgiveness, someone who is guilty is not sentenced or does not need to feel the punishment. Provisions such as this basically exist in conditional criminal conduct (voorwaardelijke veroordeling) regulated in Article 14a-14f of the Criminal Code. Conditional penalties are also referred to by part of the community with the term criminal trial or there is also termed as conditional punishment.

\subsection{Application of the Rechterlijk Pardon Principle in Criminal Decision Ruling Number 241 / Pid.B / 2019 / PN.Mjl}

Development in the field of law, specifically the development or renewal of criminal law, not only builds legal institutions, but must also include the development of the substance of legal products which are the result of a legal system in the form of criminal and cultural legal regulations, namely attitudes and values that affect the implementation of the legal system. ${ }^{13}$

Excessive use of the agency is also common in common law countries. One of the horrendous cases was the granting of amnesty / pardon by King of Charles II to Danby as prime minister, who at that time was to be impeached by the British Parliament for a criminal offense. This incident became very strange because in the constitutional monarchy, the king as head of state never rejected an impeachment carried out by parliament against

\footnotetext{
${ }^{11}$ Mufatikhatul Farikhah, "The Concept of Judicial Pardon in Indigenous Communities in Indonesia", Journal of Legal Media, Vol. 25, No. 1, June 2018, p. 82

${ }^{12}$ Results of an interview with Eti Koerniati, $\mathrm{SH}, \mathrm{MH}$, as a Judge in the Majalengka District Court, on January 22,2020 , at 13.45 WIB

${ }^{13}$ Satjipto Rahardjo, 1980, Hukum dan Masyarakat. Angkasa. Bandung, p. 84-86
} 
the prime minister, not only that the use of the king's forgiveness agency to stop the impeachment became something that did not make sense. In addition, King of Charles II has also sold pardons / amnesty for 2 shillings to every criminal. This act was strongly opposed by Luther and the law reformers,

Court decisions related to the Forgiveness Agency (Rechterlijk Pardon) are not just Decision of Majalengka Court Number 241 / Pid.B / 2019 / PN. The decision received attention and attention from the community, because both involved the son of an official in this country. What happened to Irfan Nur Alam, son of $\mathrm{H}$. Karna Sobahi Regent who was serving in Majalengka Regency. However, the peace that occurred between the defendant and the victim or family in the two cases did not make the two cases the judge decided acquitted, only used as a mitigating consideration. ${ }^{14}$

Application of the Rechterlijk Pardon Principle in Criminal Verdicts Number 241 / Pid.B / 2019 / PN.Mjl isapplied later will act as the final safety valve in the criminal justice system if a case is not filtered out at the prosecution and preliminary hearing judges. The judge in giving the Rechterlijk Pardon decision must be based on the guidelines as stated in Article 60 Paragraph (2) RKUHP 2018, namely the lightness of the action, personal circumstances of the maker, or the condition at the time the act was committed or what happened then, so that it can be used as a basis for consideration not to impose a criminal or impose a criminal action by considering aspects of justice and humanity. The decision to be implemented will be in the form of a judge's forgiveness or pardon rechecking decision.

\subsection{Development / concept of the Rechterlijk Pardon principle in the upcoming renewal of Indonesian criminal law is related to the draft criminal law in the monodualistic principle}

The regulation on Rechterlijk Pardon cannot only be regulated in the RKUHP, because the RKUHP only contains material criminal law. Even the provisions of the judge's forgiveness are not known beforehand in the current Penal Code. Therefore, Rechterlijk Pardon arrangements must be harmonized with the RKUHAP going forward. So that the article about the institution of forgiveness of judges is not just a "death article", which cannot be implemented in practice at trial. This concern arises when critically observing the RKUHAP regulation related to the possible forms of verdicts that can be handed down to a defendant. The forgiveness of judges (rechterlijk pardon) as something new, which is given to the judicial authority and is another form of judge's decision in the process of reforming criminal law through the draft of the Criminal Code Bill, so to be able to know its benefits as a sanction law is in harmony with the understanding of harmony between pillars of law enforcement; of course proportional harmonization is needed in its regulation and implementation after it is completed or motivated by a conceptual understanding of what is meant by the renewal of criminal law itself in the dynamic development of law as ius constituendum, and other concepts related to the understanding of the pardon recharge given to judicial authority with the executive power held by the present Penal Code (amnesty) so as to produce a further pardon judicial understanding of how potential implementation. It means that the existence of the regulation in the renewal of criminal law truly describes an effort to reform the criminal law rather than vice versa which precisely illustrates a setback.

\footnotetext{
${ }^{14}$ Results of an interview with Eti Koerniati, $\mathrm{SH}, \mathrm{MH}$, as a Judge in the Majalengka District Court, on January 22,2020 , at 13.45 WIB
} 
To understand clearly the purpose or reasons for regulating rechterlijk / judicial pardon / dispensation de pen in the Indonesian criminal law system (RUU KUHP), the authors argue that this is regulated as a way out or a solution to imprisonment of short imprisonment and prevent unnecessary imprisonment seen from the aspect of its needs related to the purpose of criminal prosecution of cases or minor criminal offenses. Complementing the opinion of the author, try to include the opinion of an expert in his writing explaining that: ${ }^{15}$ "Behind the regulation on dispensa de pen, not only to avoid the imprisonment of short imprisonment but also to prevent unjustified punishment from the aspect of the need to protect the community and rehabilitate the offender". However, the effectiveness of its application is not as easy as we think, especially with regard to the principles of justice and the usefulness of the law for the purpose of law enforcement and criminal objectives.

Development / Concept of the Rechterlijk Pardon Principle in the Future Renewal of Indonesian Criminal Laws Associated with the Draft Criminal Laws on the Monodualistic Principle are Forgiveness institution, is an important element to answer problems that cannot be accommodated with only 3 (three) types of decisions (free, loose, criminal funds). Second, forgiveness institutions also have 2 main objectives, namely: (1) In the context of alternative short prison (alternative penal measures to imprisonment), and (2) Judicial corrections to the principle of legality (judicial corrective to the legality principle). Third, the obscurity of the four signs / guidelines / in imposing a pardon verdict, namely (1) the lightness of the action, (2) the personal state of the maker, (3) the state at the time the act was committed or ensues, and (4) Considering the aspects of justice and humanity.

\section{Closing}

\subsection{Conclusion}

- The position of the Rechterlijk Pardon Principle in the Criminal System in Indonesia is forgiveness is a form of forgiveness / deliverance from mistakes made. As a form of forgiveness, then with forgiveness, someone who is guilty is not sentenced or does not need to feel the punishment. Provisions such as this basically exist in conditional criminal conduct (voorwaardelijke veroordeling) regulated in Article 14a-14f of the Criminal Code. Conditional penalties are also referred to by part of the community with the term criminal trial or there is also termed as conditional punishment.

- Application of the Rechterlijk Pardon Principle in Criminal Verdicts Number241 / Pid.B / 2019 / PN.Mjlit is applied later to act as the final safety valve in the criminal justice system if a case is not filtered at the prosecution and preliminary hearing judge stage. The judge in giving the Rechterlijk Pardon decision must be based on the guidelines as stated in Article 60 Paragraph (2) RKUHP 2018, namely the lightness of the action, personal circumstances of the maker, or the condition at the time the act was committed or what happened then, so that it can be used as a basis for consideration not to impose a criminal or impose a criminal action by considering aspects of justice and humanity. The decision to be implemented will be in the form of a judge's forgiveness or pardon rechecking decision.

- Development / Concept of the Rechterlijk Pardon Principle in the Future Renewal of

\footnotetext{
${ }^{15}$ Barda Nawawi, 2003, Beberapa Masalah Perbandingan Hukum PIdana, Raja Grafindo Persada, Jakarta, p. 85
} 
Indonesian Criminal Laws Associated with the Draft Criminal Laws on the Monodualistic Principle are Forgiveness institution, is an important element to answer problems that cannot be accommodated with only 3 (three) types of decisions (free, loose, criminal funds). Second, forgiveness institutions also have 2 main objectives, namely: (1) In the context of alternative short prison (alternative penal measures to imprisonment), and (2) Judicial corrections to the principle of legality (judicial corrective to the legality principle). Third, the obscurity of the four signs / guidelines / in imposing a pardon verdict, namely (1) the lightness of the action, (2) the personal state of the maker, (3) the state at the time the act was committed or ensues, and (4) Considering the aspects of justice and humanity.

\subsection{Suggestion}

- As a country based on the Almighty God as regulated in Article 29 of the 1945 Constitution, then the forgiveness agency (Rechterlijk Pardon) has a reason to be enacted in the criminal code guidelines in positive national applicable law that will come.

- Forgiveness institutions (Rechterlijk Pardon) which are already in the draft of the Criminal Code Bill-September 2019, should be maintained and endorsed as one of the articles that must be defended and ratified, if there are still deficiencies that can be revised by not eliminating the meaning and purpose of the forgiveness institution (Rechterlijk Pardon ).

- Forgiveness institutions (Rechterlijk Pardon) applied between perpetrators and victims or victims' families, should also be considered to apply if the victims are institutions or countries, the author's policy is left to legal experts and later researchers.

\section{References}

[1] Achmad Sulchan, 2017, Catatan Kuliah Teori Hukum dan Penemuan Hukum, Lecturer of Faculty of Law, Unissula, Semarang.

[2] Agus Rusianto, 2016, Tindak Pidana \& Pertanggungjawaban Pidana: Tinjauan Kritis Melalui Konsistensi antara Asas, Teori, dan Penerapannya, Kencana, Jakarta

[3] Andi Hamzah, 1986, Sistem Pidana dan Pemidanaan Indonesia dari Retribusi ke Reformasi, $1^{\text {st }}$ print, Pradnya Paramita, Jakarta

[4] Bambang Poernomo, 1993, Asas-asas Hukum Pidana, Ed. Revised, Ghalia Indonesia, Jakarta

[5] Barda Nawawi, 2003, Beberapa Masalah Perbandingan Hukum Pidana, Raja Grafindo Persada, Jakarta

[6] Eva Achjani Zulfa, 2011, Pergeseran Paradigma Pemidanaan, Lubuk Agung, Bandung

[7] Harkristuti Harkrisnowo, 2003, "Rekonstruksi Konsep Pemidanaan: Suatu Gugatan Terhadap Proses Legislasi dan Pemidanaan di Indonesia," Oration at the Inauguration Ceremony of Professors in Criminal Law, Faculty of Law, University of Indonesia at the University of Indonesia Convention Center, Depok March 8, 2003

[8] Results of an interview with Eti Koerniati, $\mathrm{SH}, \mathrm{MH}$, as a Judge in the Majalengka District Court, on January 22, 2020, at 13.45 WIB

[9] Mufatikhatul Farikhah, "The Concept of Judicial Pardon in Indigenous Communities in Indonesia", Journal of Legal Media, Vol. 25, No. 1, June 2018

[10] Satjipto Rahardjo, 1980, Hukum dan Masyarakat. Bandung

[11] Tolib Setiady, 2010, Pokok-Pokok Hukum Penitensier Indonesia, Alfabeta, Bandung 